\title{
"Assessment of financial and economic security of the region (based on the relevant statistics of the Donetsk region)"
}

\begin{tabular}{|c|c|}
\hline AUTHORS & $\begin{array}{l}\text { Bogdan Derevyanko (D https://orcid.org/0000-0001-7408-8285 } \\
\text { R https://publons.com/researcher/2454637//bogdan-derevyanko/ } \\
\text { Liudmyla Nikolenko (D https://orcid.org/0000-0002-3437-6968 } \\
\text { Irina Syrmamiik (D https://orcid.org/0000-0003-0524-6731 } \\
\text { Yevgen Mykytenko D https://orcid.org/0000-0002-2797-381X } \\
\text { losif Gasparevich }\end{array}$ \\
\hline ARTICLE INFO & $\begin{array}{l}\text { Bogdan Derevyanko, Liudmyla Nikolenko, Irina Syrmamiik, Yevgen Mykytenko } \\
\text { and losif Gasparevich (2018). Assessment of financial and economic security of } \\
\text { the region (based on the relevant statistics of the Donetsk region). Investment } \\
\text { Management and Financial Innovations, 15(4), 283-295. } \\
\text { doi:10.21511/imfi.15(4).2018.23 }\end{array}$ \\
\hline DOI & http://dx.doi.org/10.21511/imfi.15(4).2018.23 \\
\hline RELEASED ON & Friday, 07 December 2018 \\
\hline RECEIVED ON & Tuesday, 17 April 2018 \\
\hline ACCEPTED ON & Thursday, 29 November 2018 \\
\hline LICENSE & $\begin{array}{l}(c) E Y \\
\text { This work is licensed under a Creative Commons Attribution } 4.0 \text { International } \\
\text { License }\end{array}$ \\
\hline JOURNAL & "Investment Management and Financial Innovations" \\
\hline ISSN PRINT & $1810-4967$ \\
\hline ISSN ONLINE & $1812-9358$ \\
\hline PUBLISHER & LLC "Consulting Publishing Company "Business Perspectives" \\
\hline FOUNDER & LLC "Consulting Publishing Company "Business Perspectives" \\
\hline
\end{tabular}

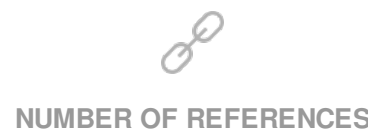

30
NUMBER OF FIGURES

2
NUMBER OF TABLES

5

(c) The author(s) 2023. This publication is an open access article. 


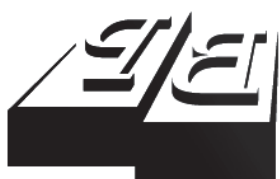

BUSINESS PERSPECTIVES

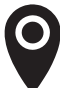

LLC “CPC "Business Perspectives" Hryhorii Skovoroda lane, 10, Sumy, 40022, Ukraine

www.businessperspectives.org

Received on: $17^{\text {th }}$ of April, 2018 Accepted on: 29 $9^{\text {th }}$ of November, 2018

(C) Bogdan Derevyanko, Liudmyla Nikolenko, Irina Syrmamiik, Yevgen Mykytenko, Iosif Gasparevich, 2018

Bogdan Derevyanko, Doctor of Law, Professor, Donetsk Law Institute of the Ministry of Internal Affairs of Ukraine, Ukraine.

Liudmyla Nikolenko, Doctor of Law, Professor, Donetsk Law Institute of the Ministry of Internal Affairs of Ukraine, Ukraine.

Irina Syrmamiik, Ph.D. Candidate in Economic Science, Associate Professor, Donetsk State University of Management, Ukraine.

Yevgen Mykytenko, Ph.D. Candidate in Law, Associate Professor, Main Department of the State Migration Service of Ukraine in Donetsk Region, Ukraine.

Iosif Gasparevich, Ph.D. Student at the Faculty of Law and Administration, University of Warsaw, Poland.

\section{(ㄷ) (1)}

This is an Open Access article, distributed under the terms of the Creative Commons Attribution 4.0 International license, which permits unrestricted re-use, distribution, and reproduction in any medium, provided the original work is properly cited.
Bogdan Derevyanko (Ukraine), Liudmyla Nikolenko (Ukraine),

Irina Syrmamiik (Ukraine), Yevgen Mykytenko (Ukraine), Iosif Gasparevich (Poland)

\begin{abstract}
In the article, the indicators of financial and economic security of Donetsk region are analyzed. The task of setting statistical estimation of financial and economic security of the region in modern conditions is based on the official materials of the State Statistics Service. For the possibility of further econometric modeling and forecasting, only quantitative indicators are used. This approach limits the number of evaluated indicators, but is considered the most objective. The analysis of financial and economic security is carried out in the context of two spheres of regional development: economic and social. The conducted analysis of the dynamics of the main socio-economic indicators of development of the Donetsk region for the period 2012-2016 allowed to identify the main trends characterizing the development of the region's economy; provide an assessment of the financial and economic security of the region and identify some "problematic" places of financial and economic security in Donetsk region. Some of the most acute problems were identified in the assessment of financial and economic security and the features of state-legal provision of financial and economic security in the present conditions, as well as the proposed algorithm for monitoring the financial and economic security of the region. The analysis allowed to identify some "bottlenecks" of financial and economic security in the Donetsk region and to demonstrate that close attention and monitoring are required by the level of capital investments, the level of unemployment and the share of households with incomes per month below the legal living wage. The study enables to minimize the risks to form effective directions in assessing the financial and economic security of the region and proposes to optimize on a legal basis the whole mechanism for ensuring the financial and economic security of the region. As a result, the research revealed the most acute problems in assessing the financial and economic security of the region and proposed an appropriate algorithm for monitoring its level.
\end{abstract}

\section{Keywords}

financial and economic security, region, evaluation, statistic, analysis, indicators of financial and economic security, integral index, legal support

\section{JEL Classification $\quad \mathrm{C} 01, \mathrm{~F} 52, \mathrm{G} 31$}

\section{INTRODUCTION}

The complicated socio-political and military situation in Ukraine, political and economic events in the world shows that the task of monitoring the financial and economic security of the region does not lose its relevance. The financial and economic security of the region is an integral part of national security, and its provision is an important element of state independence, a condition for the socio-economic development of the regions and the country as a whole on the basis of creating legal, economic, institutional, organizational and technological conditions that meet the challenges of the time. 
The foundation of the "security" approach to regional development is laid down in Article 132 of the Constitution of Ukraine, which states that "the territorial structure of Ukraine is based on the principles of unity and integrity of the state territory, a combination of centralization and decentralization in the exercise of state power, balance and socio-economic development of the regions, taking into account their historical, economic, ecological, geographical and demographic features, ethnic and cultural traditions" (Constitution of Ukraine, 1996).

The analysis of the approaches of economists to understand the essence of the term "financial and economic security of the region" has revealed that its definition is not completely formed and unambiguous, but it is a complex multifactor category that characterizes the level of openness of the economy, the ability of the region to self-finance and improve the quality of life of the population.

Thus, the financial and economic security of the region determines, first of all, the level of socio-economic development of the region and indicates the degree of independence of the region. The consequences of the fact actual military situation in the Donetsk region are the destruction of the infrastructure (production, transport, social) of the region and cities, the threat of bankruptcy of certain industries and industrial facilities, the reduction of the number of available population (migration of residents of the region to other regions of Ukraine or abroad, civilians), and as a result of this - a significant deterioration in the indicators of socio-economic development of the Donetsk region.

Financial and economic security requires an integrated study in terms of both economics and law. It should be aimed at promoting the economic development of all business entities, the introduction of social and economic standards and guarantees recognized by the European Community, as well as the modernization of relevant legislation.

\section{LITERATURE REVIEW}

A significant number of scientists' work today is devoted to finding ways to end the hybrid RussianUkrainian war and to ensure the rights and interests of Ukrainian citizens and business entities that remained on the temporarily uncontrolled government of Ukraine in the Autonomous Republic of Crimea, in the territories of Donetsk and Luhansk regions or that relocated (produced production assets) to the territory where Ukrainian laws are fully applicable.

Grant (2015) examines the annexation of Crimea in view of the legal arguments that the Russian Federation has articulated in defense of its actions. It then considers the international response and the possible consequences of nonrecognition. Katchanovski (2016) examines the role of separatists, the Yanukovych government, the Maidan opposition and the Maidan government, far-right organizations, Russia, the US, and the EU in the conflict in Donbas. The Kyiv International Institute of Sociology survey shows that support for separatism is much stronger in Donbas compared to oth- er regions, with the exception of Crimea, and that the break-up of Ukraine is unlikely to extend to its other parts (Katchanovski, 2016).

Freedman (2014) explores the relevance of the strategic concepts of the Cold War in the eastern part of Ukraine, the deterioration of relations between Russia and the West, the strengthening of the role of Russian troops in Ukraine, the implications for the civilian population, etc. Cullen Dunn and Bobick (2014), based on the study of Russian behavior in Eastern Ukraine, argue that the pervasive fear created by Eurasia's frozen conflicts constitutes a new form of post-Soviet liminality that challenges the norms of the international system. Malyarenko (2015) explores the relationship between Kyiv and Donbass, recognizing Russia's main role in the initiation, development and escalation of armed conflict. Kuzio (2016) analyzes three factors constraining EU power: its unwillingness to view Ukraine as a candidate for membership, a miscalculation of Ukrainian leaders and the ignorance of growing nationalism and xenophobia in Russia. These three factors restrict the EU's ability to respond to the Russian-Ukrainian crisis by ignoring Russia's past 
support for separatist movements and the invasion of Georgia and the recognition of two separatist anklaves (Kuzio, 2016).

Semigina and Gusak (2016) focus on social support for IDPs in Ukraine. This paper explores the social work interventions in the aftermath of the violence available to displaced people and the gap in them. It also discusses implications for the social work profession, caused by the ongoing conflict in the country. Coupé and Obrizan (2016) investigate the impact of violence suffered by the residents of the two cities most affected by the hybrid war (Sloviansk and Kramatorsk) on the results of the election.

However, a large number of studies have not yet solved the existing problems in the economy and social area of the region, which is suffering from the actual war. Its financial and economic security is under serious threat.

Many scientists conducted the research aimed at solving the problem of assessing the financial and economic security of the region.

Ensuring the economic security of the region, according to Efremov and Georgadze (2002), is a guarantee of the country's independence, a condition for the stability and effective life of the society, and for success. They offer a methodology for monitoring the system of socio-economic indicators on the basis of taking into account the limit values of these indicators and indicate that only in the presence of boundary values that have an assessment taking into account the characteristics of the region's economy, it is possible to assess the level of the crisis situation in one or another sphere.

Heyets, Chernyak, and Klebanova (2011) point out the importance of limiting values in their work. They, as well as Ponomarenko, Klebanova, and Chernova (2004), consider that the issue of studying the financial and economic security of the region is important, taking into account socioeconomic factors and their limit values, ignoring which hinders the normal course of economic development and leads to the formation of destructive trends in production and living standards of the population (Ponomarenko, Klebanova, \& Chernova, 2004).
Weisbrod (2008) critically examines the coverage of access impacts by various types of predictive economic impact models, and then describes new directions in applied models to assess transportation projects impacts on business productivity, growth and attraction. Finally, it outlines an analysis framework, which is designed to facilitate use of improved modeling methods for assessing economic impacts of multi-modal transportation investment (Weisbrod, 2008).

A systemic approach to assessing the financial and economic security components proposed by Sukhorukov and Kharazishvili (2011) deserves attention. They confirm weighting factors in terms of components of economic security, and tested these approaches with an example of estimating and forecasting the level of economic security (Sukhorukov \& Kharazishvili, 2011). In their view, the assessment of economic security should be carried out according to such an algorithm: the identification of functional characteristics of economic security; the segmentation of structural components of economic security; definition of indicators of economic security; determination of normative values of indicators of economic security; monitoring of indicators, hierarchical harmonization of results and their analysis (Sukhorukov \& Kharazishvili, 2011).

American researchers in socio-economic relations Ó hUallacháin and Leslie (2007) propose a contrastive knowledge production function and a regional structure model to identify determinants of commercial patenting in US states in the period 2002-2004. Results show that human capital, specialized knowledge flows, urbanization and industrial dominance in technical advancement of commercial patenting (Ó hUallacháin \& Leslie, 2007).

Gerasimchuk and Vavdiyuk (2010) explore the issues of analysis and mechanism of providing economic security of the region, emphasizing the importance of foreign economic security of the region, and use such characteristics as the level of foreign economic openness.

At the legislative level, a methodology is proposed for assessing the level of financial and economic security of Ukraine, developed by specialists of the Ministry of Economic Development and Trade 
of Ukraine and recommended to executive authorities, scientific and other institutions to use within their competence to determine the level of components of financial and economic security and to make managerial decisions regarding analysis, prevention and neutralization of actual and potential threats in the relevant field (Ministry of Economic Development and Trade of Ukraine, 2013). Its use is important in the activities of state and local government bodies in order to protect the financial and economic security of the state and regions.

According to Chekhovich (2013), the use of data to calculate economic security in a methodology developed at the legislative level is a complicated process, and for the greater efficiency of such an analysis, there is a need to evaluate this indicator in a more accessible way. The proposed matrix-graphic model makes it possible to identify patterns and provide further suggestions for improving socioeconomic indicators.

From a legal point of view, financial and economic security is seen as a component of national security, which is vital to the development and establishment of the state. The main normative acts of regulation of the investigated category are the Constitution of Ukraine (Constitution of Ukraine, 1996), the Economic Code of Ukraine (Economic Code of Ukraine, 2003), The Law of Ukraine "About the fundamentals of national security in Ukraine" (The Law of Ukraine "About the fundamentals of national security in Ukraine", 2003), other normative acts. From the analysis of various legislative acts and opinions of scientists, the concept of "financial and economic security" can be interpreted as a state of protection of the state's economy from negative external and internal influence, aimed at the development of society and the state as a whole, ensuring economic, social, financial and political stability. Ensuring the financial and economic security of the region can be defined as a developed mechanism aimed at creating conditions for the activities of economic entities in a defined territory in order to increase economic growth and decent living standards of the population of this region. The basic norms of the economic legislation create a solid legal basis for ensuring financial and economic security at the micro-level (level of economic entities), but not on the meso-level (level of regions).
An analysis of research conducted by domestic scientists indicates the existence of a sufficiently diverse approach to assessing the financial and economic security of the regions. At the same time, the lack of a unified methodology for studying the problem of assessing the indicators of financial and economic security of regions, the lack of systemicity and inconsistency of normative documents, suggests that at the regional level, these issues are still incompletely resolved or remain controversial.

The financial and economic security of the region determines the level of socio-economic development of the region, its integration with the country's economy and indicates the degree of independence of the region. Financial and economic security - a category which is in constant motion and varies under the influence of a huge number of factors. In Greek, "security" means "to have a situation", and this is possible only by generalizing the data of these factors with the use of statistical techniques and methods.

\section{METHODS}

In order to analyze the financial and economic security of the region, it is proposed to use a system of indicators that consists of two components that characterize the security situation, and their statistical analysis in a dynamics will enable to identify the most threatening trends and form effective ways to counteract the emergence of threats and minimize them within the framework of the implementation of regional policy. The list of key indicators for the components "Economic sphere" and "Social sphere", which are proposed to assess the financial and economic security of the region, is given in Table 1. Using standardization, the article succeeded in bringing the whole system of indicators of financial and economic security of the Donetsk region to a single integral index, and by comparison - comparing the system of indicators with the value adopted for the comparison basis. This, in turn, made it possible to standardize the system of indicators of financial and economic security of the Donetsk region. The application of the methods of analysis and synthesis made it possible to investigate changes 
in the system of the basic economic indicators of activity of enterprises of the Donetsk region, to reveal certain regularities and to establish a causal relationship with the political situation in the region, Ukraine and the world. Also, by comparison, certain socio-economic indicators of the Donetsk region with corresponding minimum, maximum and average values of similar national indicators were correlated and compared, and conclusions were drawn about the necessity and possibility of increasing them.

The objective of this study in the analysis of the economic and social components of the financial and economic security of the Donetsk region on the basis of official publications of the State Statistics Service to identify the most acute problems in assessing financial and economic security and to identify the features of state-legal provision of financial and economic security of the region in modern conditions; in the proposal of the algorithm for monitoring the level of financial and economic security of the region.

\section{RESULTS}

Table 1 lists the financial and economic security components of the regions. This list, of course, is not exhaustive and can be supplemented depending on the depth and purpose of the study. However, it should help to characterize qualitatively and quantitatively the state of financial and economic security of a separate region on the example of the Donetsk region of Ukraine.
Table 1. A list of key indicators for the components of regional economic security

\begin{tabular}{|c|c|}
\hline Components & Safety indicators \\
\hline \multirow{4}{*}{ Economic } & Gross Regional Product (GRP) \\
\hline & Industrial production index \\
\hline & Agricultural product index \\
\hline & $\begin{array}{l}\text { Capital investment in the region (in actual } \\
\text { prices, million UAH) }\end{array}$ \\
\hline \multirow{3}{*}{ Social } & Unemployment rate \\
\hline & The average monthly salary \\
\hline & $\begin{array}{l}\text { The share of households with per capita } \\
\text { equivalent cash income per month is below } \\
\text { the statutory minimum subsistence level }\end{array}$ \\
\hline
\end{tabular}

In analyzing the economic situation and the development of regions, a generalized indicator such as Gross Regional Product (Table 2) is widely used. As the analysis shows, the Gross Regional Product of Donetsk region for 2012-2015 dropped by 1.5 times, although in Ukraine it increased by 1.4 times. During these three years, the contribution of the economy of Donetsk region to the economy of Ukraine has decreased from $12.16 \%$ to $5.78 \%$. And, above all, these are disturbing signals that indicate a worsening of the investment situation, and the low financial performance of enterprises in Donetsk region by major types of economic activity.

The decline in the main socio-economic indicators of the Donetsk region began in 2014. As of September 2014, out of 93 mines in the region subordinated to the Ministry of Energy and Coal Industry, 24 worked in the normal mode, 58 were in life support (ventilation and sanitation), 11 were completely exhausted (Information and

Table 2. Value of key indicators of the economic sphere

Source: State Statistics Service of Ukraine (2017).

\begin{tabular}{|c|c|c|c|c|c|c|c|c|c|}
\hline \multirow[b]{2}{*}{ Years } & \multicolumn{3}{|c|}{$\begin{array}{c}\text { Gross Regional Product (in actual } \\
\text { prices, mln. UAH) }\end{array}$} & \multicolumn{2}{|c|}{$\begin{array}{l}\text { Indices of industrial } \\
\text { production }\end{array}$} & \multicolumn{2}{|c|}{$\begin{array}{l}\text { Indices of } \\
\text { agricultural } \\
\text { products }\end{array}$} & \multicolumn{2}{|c|}{$\begin{array}{l}\text { Capital investment } \\
\text { by region (in actual } \\
\text { prices, mln. UAH) }\end{array}$} \\
\hline & $\begin{array}{l}\text { Donetsk } \\
\text { region }\end{array}$ & Ukraine & $\begin{array}{c}\text { Specific } \\
\text { gravity of } \\
\text { the GRP to } \\
\text { the total } \\
\text { GRP, in } \%\end{array}$ & $\begin{array}{l}\text { Donetsk } \\
\text { region }\end{array}$ & Ukraine & $\begin{array}{l}\text { Donetsk } \\
\text { region }\end{array}$ & Ukraine & $\begin{array}{l}\text { Donetsk } \\
\text { region }\end{array}$ & Ukraine \\
\hline 2012 & 170,775 & $1,404,669$ & 12.16 & 94.6 & 99.3 & 94.8 & 96.1 & $31,721.9$ & $273,256.0$ \\
\hline 2013 & 164,926 & $1,465,198$ & 11.26 & 93.6 & 95.7 & 105.8 & 113.6 & $27,912.4$ & $249,873.4$ \\
\hline 2014 & 119,983 & $1,586,915$ & 7.56 & 68.5 & 89.9 & 93.0 & 102.2 & $13,155.3$ & $219,419.9$ \\
\hline 2015 & 115,012 & $1,988,544$ & 5.78 & 65.4 & 87.0 & 64.9 & 95.2 & $8,304.3$ & $273,116.4$ \\
\hline 2016 & \multicolumn{3}{|c|}{$\begin{array}{l}\text { No official data available as of March } \\
\qquad 2018\end{array}$} & 106.4 & 102.8 & 108.3 & 106.3 & $11,902.2$ & $359,216.1$ \\
\hline
\end{tabular}




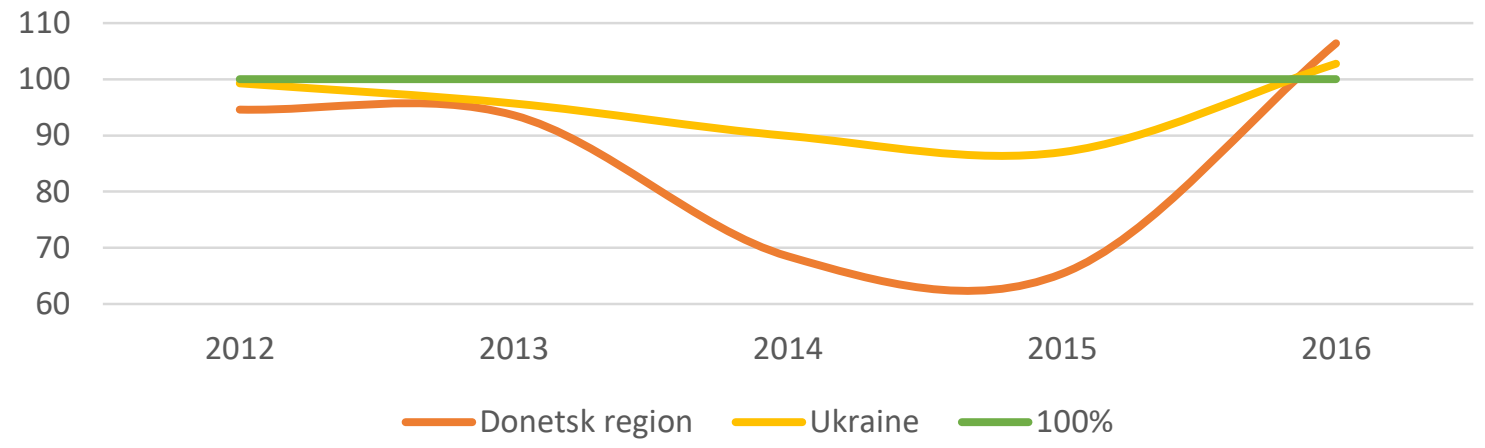

Figure 1. Dynamics of indices of industrial production for 2012-2016

Analytical Center of the National Security and Defense Council, 2014). Only in 2014, volumes of industrial production decreased in Donetsk region - by $31.5 \%$, in Luhansk - by $42.0 \%$. In particular, in the Donetsk region, the decline in industrial production amounted to: $18.3 \%$ in the production, transmission and distribution of electricity; in metallurgical production and production of finished metal products $-27.7 \%$; in the production of coke and refined products $-31.5 \%$; in the coal industry - 36.8\%; in machine building - $41.1 \%$; in the manufacture of chemicals and chemical products - 47.5\% (Libanova, Amosha, Vyshnevskyy, Heyets et al., 2015, p. 46).

Since the beginning of hostilities, the fall of all economic indicators of the Donetsk and Luhansk regions has been above average in Ukraine. Thus, in 2014, when Ukraine reduced its commodity exports by $13.5 \%$, compared to the previous year, its reduction in the Donetsk region amounted to $32.3 \%$, in Luhansk - 46.3\%. In January-August 2015, Ukraine's commodity exports declined by $39.9 \%$ compared to the same period in 2014 , while the decline in Donetsk region amounted to 61.9\%. If in 2013 Donetsk and Luhansk regions together provided $25.2 \%$ of Ukraine's commodity exports, then in 2014 - only 19.1\%, and in 2015 - $10.6 \%$ in total (Horbulin, Vlasyuk, Libanova, Lyashenko et al., 2015, p. 161). Economic activity on temporarily uncontrolled territories of Ukraine decreased by 5 times. In 2014, industrial output fell by $31.5 \%$ in Donetsk region, by $42.0 \%$ in Luhansk. Budget losses amount to $20 \%$ (Libanova, 2015, p. 19). If in 2013, the share of coal in the import of mineral fuels amounted to $9.2 \%$, then in $2014-11.7 \%$, and in JanuaryJuly 2015 - 16.4\% (Horbulin, Vlasyuk, Libanova, Lyashenko et al., 2015, p. 163).
The volume of industrial production in the Donetsk region (excluding the part of the ATO zone) decreased by $48.2 \%$ in January-July 2015 (for January-June this figure was $49.9 \%$, i.e. the halfyearly volume of production was reduced by a factor of 2). In July 2015, the recession slowed down to $36.0 \%$, while in June it was $46.6 \%$, in May it was 45.9\%, in April it was 9.5\% (Libanova, Amosha, Vyshnevskyy, Heyets et al., 2015, p. 45).

The negative effects of actual military actions were felt by the labor market of the Donetsk region. So, as of 2015, job losses were estimated at $50 \%$ for large enterprises to $80-90 \%$ for small and medium-sized enterprises in the region. As a result, from 1.1 to 1.8 million able-bodied people in the Donbas, part or all of them were left without work and livelihood, which led to the emergence of almost 2 million people in economically inactive population (Libanova, 2015, p. 18).

The index of industrial production testifies to the real decline of the economy in the Donetsk region and in Ukraine as a whole. This indicator only in 2016 rose above the mark at $100 \%$, and in other years, it was lower than $100 \%$ (Figure 1).

The results of the analysis show that certain indices of agricultural production indices in the Donetsk region have increased, which increased in 2013, but declined in 2014 and 2015 (Figure 2).

Investments are the determining factor in economic development and modernization of the region. In general, in 2012-2016, an ambiguous situation was observed. In 2013, there was a reduction of investments in the region and in general in Ukraine, which was due to the beginning of an unstable situation on the territory of Ukraine, 


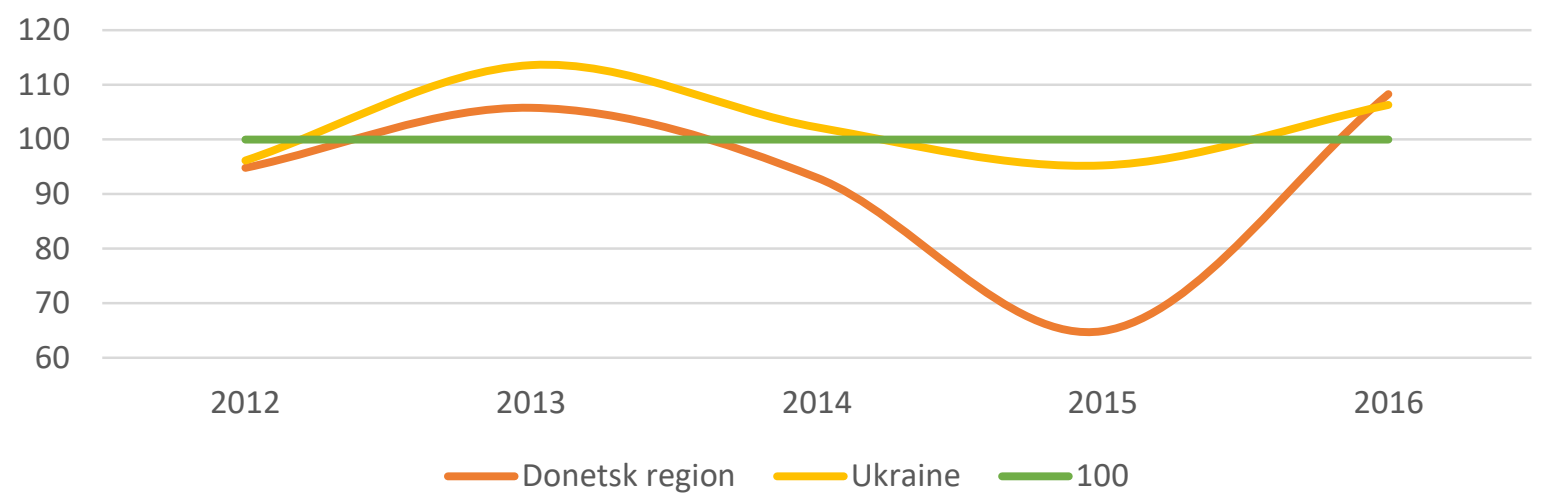

Figure 2. Dynamics of agricultural production indices for 2012-2016

which threatened investors' finances. The data of capital investments of the Donetsk region at the expense of all sources of financing point to positive changes in the economy of Ukraine in 2016 compared to 2015, but enterprises and organizations have been mastered this year by $63 \%$ less than in 2012. In 2015, the situation with the volume of capital investments in Ukraine has improved, but in the region, the consequences of instability were significant - in comparison with 2014, volumes decreased by almost $37 \%$.

One of the directions for raising the level of social and economic development of the region and ensuring its safety is the inclusion and assessment of social indicators (Table 3 ).

An important social factor affecting the financial and economic security of the region is the unemployment rate of the population. The value of this

Table 3. The value of key social sector indicators indicator since 2012 is increasing, reflecting the tendency of a significant deterioration of the social component initially after the global financial crisis, and then the military aggression against Ukraine. As a result of hostilities, most of the productions and industrial enterprises in the region ceased their activities, thus creating the problem of unemployment. According to the methodology of the International Labor Organization, the threshold value for unemployment is $8 \%$ of the working population, which is why practically in the years 2012-2016 the Donetsk region is in danger, indicating a low involvement of the able-bodied population in active work. The danger increases due to the geographical proximity to the places of actual conduct of hostilities and the presence of a significant number of unrecorded weapons and persons carrying out its transportation and sale. Lack of work and livelihood can induce individuals to engage in unlawful activities. And here in the first

Source: State Statistics Service of Ukraine (2017).

\begin{tabular}{|c|c|c|c|c|c|c|c|c|}
\hline \multirow{3}{*}{ Years } & \multicolumn{4}{|c|}{ Unemployment rate, \% } & \multicolumn{2}{|c|}{$\begin{array}{c}\text { Average monthly } \\
\text { salary, UAH }\end{array}$} & \multicolumn{2}{|c|}{$\begin{array}{l}\text { Percentage of households with per } \\
\text { capita equivalent cash income a } \\
\text { month lower than the statutory } \\
\text { subsistence minimum, \% }\end{array}$} \\
\hline & \multicolumn{2}{|c|}{ Donetsk region } & \multicolumn{2}{|c|}{ Ukraine } & \multirow[b]{2}{*}{ Ukraine } & \multirow[b]{2}{*}{$\begin{array}{c}\text { Donetsk } \\
\text { region }\end{array}$} & Donetsk region & Ukraine \\
\hline & $\begin{array}{c}\text { Of all at } \\
\text { the age of } \\
15-70 \text { years }\end{array}$ & $\begin{array}{c}\text { Of them } \\
\text { employable } \\
\text { age }\end{array}$ & $\begin{array}{l}\text { Total, at } \\
\text { the age } \\
\text { of } 15-70 \\
\text { years }\end{array}$ & $\begin{array}{c}\text { Of them } \\
\text { employable } \\
\text { age }\end{array}$ & & & $\begin{array}{l}\text { In the number of } \\
\text { households in the } \\
\text { corresponding } \\
\text { group of Donetsk } \\
\text { region }\end{array}$ & $\begin{array}{l}\text { In the number of } \\
\text { households in the } \\
\text { respective group } \\
\text { of Ukraine }\end{array}$ \\
\hline 2012 & 8 & 8.5 & 7.5 & 8.1 & 3,025 & 3,495 & 4.9 & 12.1 \\
\hline 2013 & 7.8 & 8.2 & 7.2 & 7.7 & 3,265 & 3,755 & 6.1 & 11.4 \\
\hline 2014 & 11 & 11.3 & 9.3 & 9.7 & 3,480 & 3,858 & 16.6 & 12 \\
\hline 2015 & 13.8 & 14.2 & 9.1 & 9.5 & 4,195 & 4,986 & 9.8 & 9.4 \\
\hline 2016 & 14.1 & 14.6 & 9.3 & 9.7 & 5,183 & 5,989 & 11.2 & 9.3 \\
\hline
\end{tabular}


place is not the financial and economic security of the region, but the national security of the state.

Some of the positive changes regarding financial and economic security in the social direction should include raising the average monthly wage. The average rate of increase in the Donetsk region was $14.4 \%$. However, in general, Ukraine's consumer price index is growing rapidly, which reduces the growth of household incomes. The low salary level of the population of regions is indicated by the ratio of average wages to the subsistence minimum. Disappointing are the indicators for households with per capita cash equivalent per month below the statutory minimum subsistence level, which also show a negative dynamics. Such a situation can lead to the destruction of labor potential, livelihoods and viability of the population.

After analyzing the state of indicators of financial and economic security in the Donetsk region and Ukraine in general for 2012-2016, and noting the decline of development indicators, it will be appropriate to focus on the comparison of indicators of the Donetsk region with minimum, maximum and average values across Ukraine. For example, in 2016 (Table 4), the Chernivtsi region was the most dangerous according to Gross Regional Product, capital investment in the region. The leader of all regions of Ukraine according to these indicators is the city of Kyiv, which also has the highest average monthly salary. The lowest unemployment rate in Ukraine defined in the Kharkiv region.
To simplify the economic interpretation of the results, we combine all the features into one common integral indicator. Since all of the above statistics have different measurement units, in order to be able to use these indicators to integrate into one overall integral, each actual value of the indicator must be standardized. After standardization, they do not have units of measurement, they become relative quantities. In the writings of scholars, there are different approaches to the standardization method. All standardization methods are based on comparisons with the value that will be accepted as the basis of comparison. Standardization of the system of indicators of financial and economic security of Donetsk region will be carried out as follows:

- for stimulators: $z_{i}=\frac{x_{i}-x_{\min }}{x_{\max }-x_{\min }}$;

- for destimulators: $z_{i}=\frac{x_{\max }-x_{i}}{x_{\max }-x_{\min }}$,

where $z_{i}$ - standardized (normalized) value of the $i$-th indicator, $x_{i}$ - the actual value of the $i$-th indicator, $x_{\min }, x_{\max }$ - the minimum and maximum value of the $i$-th indicator in Ukraine.

The stimulators in our study include:

- Gross Regional Product (Z1);

- industrial production index (Z2);

Table 4. Value of indicators of financial and economic security of Donetsk region in 2016

\begin{tabular}{|c|c|c|c|c|}
\hline Safety indicators & Minimum in Ukraine & $\begin{array}{l}\text { Maximum in } \\
\text { Ukraine }\end{array}$ & $\begin{array}{l}\text { The value of the } \\
\text { indicator in the } \\
\text { Donetsk region }\end{array}$ & $\begin{array}{l}\text { Average } \\
\text { for } \\
\text { Ukraine }\end{array}$ \\
\hline \multicolumn{5}{|c|}{ For stimulators } \\
\hline Gross Regional Product, UAH million & 21,239 (Chernivtsi region) & 559,140 (Kyiv) & 137,500 & $95,414.68$ \\
\hline Industrial production index & 91.2 (Sumy region) & $\begin{array}{l}139.0 \text { (Luhansk } \\
\text { region) }\end{array}$ & 106.4 & 105.012 \\
\hline Agricultural product index & 96.8 (Zaporizhzhia region) & $\begin{array}{l}119.3 \text { (Luhansk } \\
\text { region) }\end{array}$ & 108.3 & 106.028 \\
\hline $\begin{array}{l}\text { Capital investment in the region, UAH } \\
\text { millions }\end{array}$ & 2,668.8 (Chernivtsi region) & 106,295.5 (Kyiv) & $11,902.2$ & $14,368.644$ \\
\hline Average monthly salary, UAH & 3,695 (Ternopil region) & 8,648 (Kyiv) & 5,989 & $4,597.96$ \\
\hline \multicolumn{5}{|c|}{ For destimulators } \\
\hline Unemployment rate, \% & 6.4 (Kharkiv region) & $\begin{array}{l}16.0 \text { (Luhansk } \\
\text { region) }\end{array}$ & 14.1 & 10,028 \\
\hline $\begin{array}{l}\text { The share of households with per capita } \\
\text { equivalent cash income per month is } \\
\text { below the statutory living wage, } \%\end{array}$ & 3.7 (Mykolaiv region) & $\begin{array}{l}21.4(\text { Volyn } \\
\text { region) }\end{array}$ & 11.2 & 9,876 \\
\hline
\end{tabular}


- $\quad$ agricultural product index (Z3);

- $\quad$ capital investment in the region (Z4);

- $\quad$ average monthly salary (per employee) (Z5).

The destimulators include:

- the unemployment rate of the population (according to the ILO methodology) (in \% to the economically active population of the corresponding age) (Z6);

- the share of households with per capita equivalent cash income per month below the statutory subsistence minimum $(Z 7)$.

The values of the obtained values of indicators will fluctuate in the range from 0 to 1 , which will allow to assess the state of the region or the value of the "average region" (average level in Ukraine).

The integral indicator of Donetsk region's financial and economic security is calculated as the average of standardized indicators:

$$
I P_{m}=\bar{Z}
$$

That is, it is assumed that the individual indicators have the same effect on the security of the region, so there is no need to determine the significance (weight) of each of the selected indicators. The results of the calculation of the standardized values of statistical indicators that affect the financial and economic security of regions and the overall integral indicator for 2016 are presented in Table 5.

According to the results of the assessment of financial and economic security of regions of Ukraine, the average value of the integral assessment in the country was 0.33436 . Despite the fact that the values of indicators in the Donetsk region are within $\left[x_{\min } ; x_{\max }\right]$, the region has an integral value below its $1.4 \%$ average. The most vulnerable places in the region are attracting capital investment of enterprises, unemployment and households with incomes a month lower than the statutory minimum subsistence level.

The analysis of the dynamics of indicators of financial and economic security shows that the state of providing financial and economic security in the Donetsk region is unstable and difficult to predict, because there are no explicit trends in the change of dynamics in a positive direction. The fall of the economy of Ukraine and the Donetsk region, which began in 2012, stopped in 2015. After that, the growth began. The gross regional product of Donetsk region for 2012-2016 has decreased by 1.25 times, although in Ukraine it grew by 1.7 times. The index of industrial production only in 2016 rose more than $100 \%$, and in other years it was below $100 \%$. Agricultural commodity indexes in Donetsk region increased in 2013, but declined in 2014 and 2015. The data of capital investments of Donetsk region at the expense of all sources of financing indicate that in 2016, in comparison with 2015, there are positive trends, but the enterprises and organizations this year are mastered by $63 \%$ less than in 2012 . The unemployment rate of the population since 2012 is increasing; most of the productions and industrial enterprises in the region ceased their activity, thereby creating the problem of unemployment. The average rate of increase in the average monthly wage in the Donetsk region was $14.4 \%$. The share of households in the Donetsk region with average per capita monetary income a month lower than the statutory subsistence minimum was $11.2 \%$ in $2016,9.8 \%$ in 2015 , and $9.3 \%$ and $9.4 \%$, respectively, in Ukraine.

The military conflict greatly deteriorates the economic potential of the Donetsk region. The industrial complex is destroyed, a significant num-

Table 5. The system of standardized values of indicators and integral indicators of financial and economic security for 2016

\begin{tabular}{l|c|c|c|c|c|c|c|c}
\hline \multicolumn{1}{c|}{ Indicator } & $\mathbf{Z 1}$ & $\mathbf{Z 2}$ & $\mathbf{Z 3}$ & $\mathbf{Z 4}$ & $\mathbf{Z 5}$ & $\mathbf{Z 6}$ & $\mathbf{Z 7}$ & $\overline{\mathbf{Z}}$ \\
\hline Donetsk region & 0.2161 & 0.3180 & 0.5111 & 0.0891 & 0.4632 & 0.1979 & 0.5763 & 0.3388 \\
\hline $\begin{array}{l}\text { Middle region } \\
\begin{array}{l}\text { Declining values } \\
\text { of standardized } \\
\text { indicators }\end{array}\end{array}$ & 0.1379 & 0.2889 & 0.4101 & 0.1129 & 0.1823 & 0.6221 & 0.6511 & 0.3436 \\
\hline
\end{tabular}


ber of production facilities and infrastructure of the region in the occupied and controlled part of Ukraine is damaged. Destabilization of the socioeconomic situation has led to negative consequences not only for the region, but also for Ukraine as a whole. The losses of the Ukrainian economy from a military conflict are due to the significant role of the Donetsk region in the sphere of industrial production, retail trade, export and import of goods and services.

The situation could be improved by a set of measures aimed at stimulating domestic and foreign investment in industry and agriculture in the region, while simultaneously introducing changes to the legislation. The state may, through the use of available means of regulating the state influence on the activities of business entities, the main of which is referred to in paragraph 2 of Article 12 of the Economic Code of Ukraine, to try to increase the main indicators of activity of enterprises in the region and the state as a whole. Among the fixed assets, the greatest effect may be from the provision of investment, tax and other benefits by the state, as well as the provision of subsidies, compensation, targeted innovations and subsidies. Although considerable use can be made of the use of state orders; effective use of licensing, patenting and quotas, technical regulation; application of norms and limits, regulation of prices and tariffs (Economic Code of Ukraine, 2003). In addition, Ukrainian legislation does not prohibit the use of other means of state regulation of economic activity.

As a result, the financial and economic security of the regions is becoming increasingly important at the present stage and provides a meaningful analysis of economic, legal, and administrative relations in the region. It is becoming more difficult for the state to solve local economic and social problems. The beginning of the transfer of powers from the center to places in Ukraine can be considered the Law of Ukraine "On the Principles of Internal and Foreign Policy", which contains Article 4 "Principles of Internal Policy in the Spheres of Local SelfGovernment Development and the Promotion of the Development of Regions" (The Law of Ukraine "On the principles of domestic and foreign policy", 2010). Based on certain Principles, the regions can solve internal problems, which are already used by local administrations in many regions and cities of Ukraine. At the microlevel, the community will overcome the difficulties in education, medicine, housing and communal services, in accordance with the current legislation and in the interests of the population, because it will better take into account the features of the region, use natural resources more efficiently, and so on. The active process of decentralization in the Donetsk region began with the announcement in October 2015 of the elections in the communities of the Dobropol, Slovyansk and Liman districts. The process is still ongoing, so much of the local issues are not yet properly worked out.

Consequently, military actions in the eastern part of Ukraine have worsened the economic and social situation in the Donetsk region, which also had a negative impact on the development of the country as a whole. Since 2016, there has been a slight economic recovery of the region. The defined indicators do not cover all areas of financial and economic security, and their list can be supplemented depending on the depth and objectives of the study. The basic principle of the selection of indicators is the suitability for annual calculations and reliability, which must be confirmed by the State Statistics Service of Ukraine. An assessment of the integral indicator of financial and economic security of the region, on which territory there are military actions, analysis of the indicator in dynamics and a timely assessment of the change during the period, will be relevant. According to the results of the assessment of financial and economic security of regions of Ukraine, the average value of the integral assessment in the country was 0.33436 , and the value in the Donetsk region is lower by $1.4 \%$. The most vulnerable places in the region are attraction of capital investments of enterprises, unemployment and households with incomes a month below the legal minimum subsistence level

Statistical data of indices of industrial production and agricultural products, capital investments in the region, shares of households with average per capita monetary income per month below the statutory minimum wage, and the average monthly wage for 2016 indicate an in- 
crease in basic sectors of the economy and business activities. According to the methodology of the International Labor Organization, the Donetsk region is only in a satisfactory state of financial and economic security alone: the excess of actual values over the thresholds is not observed (Ministry of Economic Development and Trade of Ukraine, 2013). But for most indicators, the region's economy is in a particularly vulnerable position, with its strategic potential is on the limit. As an example, the approaching unemployment rate to the maximum allowable value indicates an increase in the threat of social stability in the region.

\section{CONCLUSION}

In order to prevent further deterioration of the indicators of financial and economic security in the Donetsk region, the provision of a systematic process for the restoration of the region and the improvement of regional policy directions it is necessary:

1) at the regional level:

- to analyze the list of industries that are leading in the districts of the region in the local programs of socio-economic development;

- to propose a list of new industries, which can be developed in the districts;

- continuously (monthly, quarterly) to monitor the socio-economic indicators in the region in comparison with the situation in Ukraine as a whole and separately in other regions for the detection and timely response to threats to the economy at the regional level;

2) at the national level:

- to provide the privileges to investors who invest in areas for the restoration of social, transport and industrial infrastructure, housing, and livelihood systems in the region;

- to develop and implement the effective measures for social support of the population (especially internally displaced persons) aimed at reducing unemployment and poverty, and raising wage standards;

- to improve the legislative and regulatory regulation of relations related to the financial and economic security of the region.

The monitoring of the level of financial and economic security of the region will help identify and timely respond to regional threats to the economy and improve regional policy. On the basis of work, we can propose the following algorithm for such monitoring: 1 - the formation of a system of indicators of financial and economic security, with the system to reduce each of the components to 3-4 most informative; 2 - collection, processing and analysis of statistical information; 3 - assessment of the socio-economic situation on the basis of analysis of the dynamics of levels of indicators of financial and economic security; 4 - forecasting of their levels, which further provides with the help of econometric modelling analysis of the interconnections of the most significant (in the context of positive influence on the financial and economic security of the region) components and indicators, the construction of multi-factor regression models for assessing the level of financial and economic security of the region; 5 - the formation of general conclusions regarding the financial and economic security of the region of Ukraine, the transfer of objective and reliable information on the status of objects of security and its possible deviations to the authorities. 
The following stages of the study can be carried out by means of correlation analysis of selected indicators of financial and economic security of regions, the construction of pairwise or multivariate regression models, by means of which it is possible to quantitatively measure the detected pre-linkage. An integral indicator of financial and economic security may be chosen as a dependent variable.

\section{REFERENCES}

1. Analytical report to the Annual Message of the President of Ukraine to the Verkhovna Rada of Ukraine "On the Internal and External Situation of Ukraine in 2017" (928 p.). Kyiv: NISS.

2. Bilik, R. R. (2015). Механізми та інструменти забезпечення економічної безпеки регіонів України в процесі децентралізації [Mekhanizmy ta instrument zabezpechennia ekonomichnoi bezpeky rehioniv Ukrainy v protsesi detsentralizatsii]. Biznes inform, 9, 67-72. Retrieved from http://nbuv.gov.ua/ UJRN/binf_2015_9_11

3. Chekhovich, G. T. (2013). Meтодичні підходи до оцінки економічної безпеки країн та регіонів [Metodychni pidkhody do otsinky ekonomichnoi bezpeky krain ta rehioniv]. Efektyvna ekonomika, 6. Retrieved from http://www.economy.nayka.com. ua/?op=1\&z=2437

4. Constitution of Ukraine (1996). Конституція України: прийнята на п'ятій сесії Верховної Ради України 28 червня 1996 року [Konstytutsiia Ukrainy: pryiniata na piatii sesii Verkhovnoi Rady Ukrainy 28 chervnia 1996 roku No. 254k/96-VR]. Retrieved from http://zakon5.rada.gov.ua/ laws/show/254\%D0\%BA/96\%D0\%B2\%D1\%80

5. Coupé, T., \& Obrizan, M. (2016, February). Violence and political outcomes in Ukraine - Evidence from Sloviansk and Kramatorsk. Journal of Comparative Economics, 44(1), 201-212. https://doi. org/10.1016/j.jce.2015.10.001

6. Cullen Dunn, E., \& Bobick, M. S. (2014). The empire strikes back: War without war and occupation without occupation in the Russian sphere of influence. American ethnologist, 41(3), 405-413. https:// doi.org/10.1111/amet.12086
7. Efremov, K. I., \& Georgadze, Ye. I. (2002). Питання оцінки економічної безпеки регіону [Pytannia otsinky ekonomichnoi bezpeky rehionu]. Pytannia statystyky, 2, 57-59.

8. Freedman, L. (2014, June-July). Ukraine and the Art of Crisis Management. Survival, 56(3), 7-38. https://doi.org/10.1080/00396338. 2014.985432

9. Gerasimchuk, Z. V., \& Vavdiyuk, N. S. (2010). Економічна безпека регіону: діагностика та механізм забезпечення [Ekonomichna bezpeka rehionu: diahnostyka ta mekhanizm zabezpechennia] (244 p.). Lutsk: Nadstirya.

10. Grant, T. D. (2015, January). Annexation of Crimea. The American Journal of International Law, 109(1), 68-95. https:// doi.org/10.5305/amerjintelaw.109.1.0068

11. Heyets, V. M., Klebanova, T. S., \& Chernyak, O. I. (2011). Моделювання економічної безпеки: держава, регіон, nідприємство [Modeliuvannia ekonomichnoi bezpeky: derzhava, rehion, pidpryiemstvo] (240 p). Kharkiv: "INZHEK" VD.

12. Horbulin, V. P., Vlasyuk, O. S., Libanova, E. M., Lyashenko, O. M. et al. (2015). Донбас і Крим: иіна повернення [Donbas i Krym: tsina povernennia] (474 p). Kyiv: NÍSD.

13. Information and Analytical Center of the National Security and Defense Council (2014). Ціна війни: економічні і соціальні наслідки конфлікту на Донбасі [Tsina viiny: ekonomichni $i$ sotsialni naslidky konfliktu na Donbasi]. Retrieved from http:// mediarnbo.org/2014/09/17/ tsina-viyni-ekonomichni-isotsialni-naslidki-konfliktu-nadonbasi/
14. Katchanovski, I. (2016). The Separatist War in Donbas: A Violent Break-up of Ukraine? European Politics and Society, 17(4), 473-489. https://doi.org/10.1080/23745118. 2016.1154131

15. Kuzio, T. (2016). Ukraine between a Constrained EU and Assertive Russia. Journal of Common Market Studies, 55(1), 103-120. https://doi. org/10.1111/jcms.12447

16. Libanova, Е. М. (2015). Відновлення Донбасу: оцінка соціально-економічних втрат і пріоритетні напрями державної політики (стенограма наукової доповіді на засіданні Президії НАН України 23 вересня 2015 p.) [Vidnovlennia Donbasu: otsinka sotsialno-ekonomichnykh vtrat i priorytetni napriamy derzhavnoi polityky (stenohrama naukovoi dopovidi na zasidanni Prezydii NAN Ukrainy 23 veresnia 2015 r.)]. Visnyk Natsionalnoi akademii nauk Ukrainy, 11, 13-25. Retrieved from http://dspace.nbuv. gov.ua/handle/123456789/90621

17. Libanova, E. M., Amosha, O. I., Vyshnevskyy, V. P., Heyets, V. M. et al. (2015). Відродження Донбасу: оцінка соціально-економічних втрат і пріоритетні напрями державної політики [Vidrodzhennia Donbasu: otsinka sotsialnoekonomichnykh vtrat i priorytetni napriamy derzhavnoi polityky] (167 p). Kyiv.

18. Malyarenko, T. (2015, December 23). Playing a Give-Away Game? The Undeclared Russian-Ukrainian War in Donbas. Small Wars Journal.

19. Methodology for calculating the level of economic security of Ukraine, approved by the order of the Ministry of Economic Development and Trade of Ukraine dated October 29, 2013 N 1277. Retrieved from http://zakon.rada. gov.ua/rada/show/v1277731-13 
20. Ó hUallacháin, B., \& Leslie, T. F. (2007, November). Rethinking the regional knowledge production function. Journal of Economic Geography, 7(6), 737-752. https:// doi.org/10.1093/jeg/lbm027

21. Ponomarenko, V. S., Klebanova, T. S., \& Chernova, N. L. (2004). Економічна безпека регіону: аналіз, оцінка, прогнозування [Ekonomichna bezpeka rehionu: analiz, otsinka, prohnozuvannia] (144 p). Kharkiv: ID "INZHEK".

22. Semigina, T., \& Gusak, N. (2016). Armed Conflict in Ukraine and Social Work Response to It. Social, Health, and Communication Studies Journal, 2(1), 1-24. Retrieved from https://journals.macewan.ca/ shcsjournal/article/view/269

23. Sukhorukov, A. I., \& Kharazishvili, Yu. M. (2011). Теоретикометодологічний підхід до інтегральної оцінки та регулювання рівня економічної безпеки держави [Teoretykometodolohichnyi pidkhid do intehralnoi otsinky ta rehuliuvannia rivnia ekonomichnoi bezpeky derzhavy]. Bankivska sprava, 4, 13-32. Retrieved from https://lib. dsau.dp.ua/book/83865

24. The Decree of the President of Ukraine "About the strategy of national security of Ukraine" dated 25.05.2015 No. 287/2015. Retrieved from http://zakon3. rada.gov.ua/laws/show/287/2015/ paran7\#n7

25. The Economic Code of Ukraine dated 16.01.2003. No. 436-IV. Retrieved from http://zakon3.rada. gov.ua/laws/show/964-15

26. The Law of Ukraine "About the fundamentals of national security in Ukraine" dated 19.06.2003 No. 964-IV. Retrieved from http://zakon3.rada.gov.ua/laws/show/964-15
27. The Law of Ukraine "On the basis of national security of Ukraine" dated 19.06.2003 No 964-IV. Retrieved from http://zakon3.rada. gov.ua/laws/show/964-15

28. The Law of Ukraine "On the principles of domestic and foreign policy" dated July 1, 2010 No. 2411-VI. Retrieved from http://zakon.rada.gov.ua/laws/ show/2411-17

29. The State Statistics Service of Ukraine (2017). Official internetagency. Retrieved from www. ukrstat.gov.ua

30. Weisbrod, G. (2008). Models to predict the economic development impact of transportation projects: historical experience and new applications. The Annals of Regional Science, 42(3), 519543. https://doi.org/10.1007/ s00168-007-0184-9 